\section{z Filologii Polskiej i Słowiańskiej}

DOI: $10.11649 /$ sfps.1736
Article No. 1736

Citation:

Szeptyński, A. (2019). Słowiński comparativus jako paralela dla rekonstruowanych zjawisk przedhistorycznych. Studia z Filologii Polskiej i Słowiańskiej, 54. https://doi.org/10.11649/sfps.1736

Rafał Szeptyński

(Instytut Języka Polskiego Polskiej Akademii Nauk, Kraków)

\title{
Słowiński comparativus jako paralela dla rekonstruowanych zjawisk przedhistorycznych
}

\section{Uwagi wstępne ${ }^{1}$}

W Gramatyce pomorskiej F. Lorentza obok wariantów sufiksu comparatiwu -ši oraz -eîši (por. pol. -sz-y: -ejsz-y) wymieniono także trzecią postać, dla której brak odpowiednika w polskim języku literackim: „Wszędzie tam, gdzie dopuszcza się sufiks -̌̌ĭ, można też posłużyć się sufiksem -ńeiši”" (GP, 1927-1937, s. 774; por. także s. 864). Por. np. gast šĩ gąstńeiñǐ 'gęstszy'. W ostatnim czasie owej kaszubskiej innowacji przypisano pewne znaczenie jako możliwej paraleli dla zjawisk dotyczących prehistorii słowiańskiego comparatiwu (por. Szeptyński, 2017, ss. 199-200); odnośne zjawiska miałyby polegać na rozszerzaniu struk-

${ }^{1}$ Niniejszym składam podziękowania p. Krzysztofowi Opalińskiemu (IBL PAN) za pomoc merytoryczną i techniczną w wykorzystaniu materiału kartoteki SPXVI (cytowane jako: Kart. SPXVI, n.d.). Artykuł nie w pełni odzwierciedla skalę owej pomocy ze względu na konieczność znacznego ograniczenia objętości tekstu (por.przyp. 9).

This is an Open Access article distributed under the terms of the Creative Commons Attribution 3.0 PL License (creativecommons.org/licenses/by/3.0/pl/), which permits redistribution, commercial and non-commercial, provided that the article is properly cited. (c) The Author(s) 2019.

Publisher: Institute of Slavic Studies, Polish Academy of Sciences

[Wydawca: Instytut Slawistyki Polskiej Akademii Nauk] 
tury wykładników stopnia wyższego o segmenty wywodzące się z formantów nieprzechodnich czasowników zmiany stanu (np. -ń- z kaszubskiego gąstńec 'stawać się gęst(sz)ym', GP, 1927-1937, ss. 843, 849). Według tej interpretacji rozszerzenie sufiksu -eišì o segment $n$ odbyło się w sposób całkiem analogiczny do, po pierwsze, rozszerzenia prasłowiańskiego sufiksu ${ }^{*}$-jbš- o segment $e^{2}$, a po drugie - samej genezy praindoeuropejskiego sufiksu ${ }^{*}$-ios- ${ }^{3}$, powstałego zapewne z przekształcenia morfemu *-(o)s- (Szeptyński, 2017, ss. 197-200).

Historia dyskusji na temat pochodzenia segmentu -ń- w kaszubskim nie jest bogata. Bodaj jedyna zaproponowana wcześniej interpretacja, przynależna samemu Lorentzowi (Lorentz, 1925, s. 133; GP, 1927-1937, s. 774), odwoływała się do dubletów positiwu: bez sufiksu oraz z sufiksem - $n$ - (GP, 1927-1937, s. 774), np. bladï bladnï 'blady' (GP, 1927-1937, s. 751) ${ }^{4}$. Uderza jednak następująca uwaga odnosząca się do wariantów sufiksalnych: „Szczególnie często pojawiają się te adjektiwa w tworach komparatywnych" (GP, 1927-1937, s. 751). Jakkolwiek trudno negować udział sufiksu przymiotnikowego - $n$ - $w$ całym procesie, wydaje się, że o przewadze comparatiwów nad positiwami pod względem wykorzystania segmentu -n-/-ń- decydować musiał jeszcze jakiś dodatkowy czynnik. ${ }^{5}$ Wspomniana już nowsza interpretacja zakłada wpływ innowacyjnego polsko-pomorskiego typu werbalnego gęstnieć (kasz. gastńec, słi. gąstnáúuc $c^{6}$ ), derywowanego od bezsufiksalnych przymiotników (gęsty, kasz./słi. gąstî). Geneza owych czasowników nie polegała zapewne na zwykłej kontaminacji odziedziczonych typów gęstnąć oraz daw. gęścieć - chodzi tu raczej o rozszerzenie podstaw derywacji dla struktur typu chłodnieć. Obok relacji chłodny $\rightarrow$ chłodnieć (obie formacje z sufiksem imiennym) zachodziła dawniej również relacja chłód $\rightarrow$ chłodną́ (bez sufiksu imiennego). Wskutek reinterpretacji czasownika chłodnąc jako pochodnego od przymiotnika chłodny prawdopodobnie zapanowała

${ }^{2}$ Skąd i odziedziczona wariantywność kasz. -šï : -eiñĭi.

3 Psł. *-jbš-, kasz. -ši.

${ }^{4} \mathrm{O}$ podobnych dubletach w polskich gwarach najobszerniej pisał Mieczysław Karaś (Karaś, 1959).

${ }^{5} \mathrm{~W}$ artykule w zasadzie pomijam rolę formantu - $n$ - w adaptacji zapożyczeń przymiotnikowych oraz w tworzeniu form pochodnych od wyrazów nieodmiennych (por. jednak 3.1, s.v. pitozzä). Choć zjawisko to dotyczy również omawianego tu działu gramatyki kaszubskiej i słowińskiej, sam nie znajduję kryteriów, które pozwoliłyby na ocenę jego znaczenia dla problemu poruszonego w niniejszym artykule. Wspominam o tym, by zachęcić Czytelników do dyskusji.

\footnotetext{
6 Z wtórnym -áu- (zob. GP, 1927-1937, s. 843).
} 
niejaka swoboda w derywacji nieprzechodnich czasowników zmiany stanu: jeżeli teraz obok chłodnieć istniało izofunkcyjne chłodnać (chłodnąć $\sim$ chłodnieć $<$ chłodny), to dzięki wspólnemu ogniwu w postaci czasowników na -nąć stosunek ten mógł być naśladowany w derywacji od przymiotnika pozbawionego sufiksu -n- (gęsty $\rightarrow$ gęstnąć $\sim$ gestnieć $)^{7}$. Na dalszym etapie innowacyjny, choć niezbyt częsty typ na -nieć ( $\mathrm{z}$ ń należącym do formantu: gęstnieć $\leftarrow$ gęsty), jako konkurencja dla powszechniejszego typu na -eć (np. mądrzeć $\leftarrow$ mądry), mógł posłużyć do odnowienia formantu comparatiwów: relacja między oboma typami werbalnymi (-ń- : -ø-) mogła zostać powielona w comparatiwach, por. słowińskie formy gastńienši : moudrìešĭ (Szeptyński, 2017, s. 199).

Celem niniejszego artykułu jest udzielenie odpowiedzi na pytanie, czy materiał rzeczywiście pozwala wnioskować o wpływie typu czasownikowego gęstnieć na upowszechnienie segmentu -ń- w kaszubskich, a zwłaszcza słowińskich comparatiwach. O ile wzmiankowane procesy prajęzykowe (praindoeuropejski i prasłowiański) stanowią zaledwie przedmiot zaawansowanej rekonstrukcji, o tyle fakty kaszubskie, jako obserwowane synchronicznie w XX w., niewątpliwie wymagają gruntownego opracowania materiałowego.

O kryteriach doboru materiału zob. punkt 2. W punkcie 3.1 referuję przykłady potencjalnie przemawiające za hipotezą Lorentza, bazującą wyłącznie na obocznych strukturach positiwu (-ø- $-n-)$. W punkcie 3.2 skupiam się na hipotezie czasownikowej. Za główne kryterium oceny przyjmuję możliwość odziedziczenia wyrazów (przymiotników i przysłówków lub czasowników na -n-, wzgl. -ń-) z dawnych epok; jako świadectwo służą tu zapisy historyczne dla polszczyzny literackiej oraz zasięgi występowania w gwarach, zwłaszcza kaszubskich ${ }^{8}$. Pozytywna weryfikacja pozwala na wniosek, że dany wyraz mógł stanowić podstawę innowacji; w przeciwnym wypadku nie sposób orzekać o kierunku oddziaływań między kategoriami. Z uwagi na konieczność ograniczenia objętości tekstu referuję wyłącznie jednostki, które uznałem za istotne dla dyskusji

7 Niewykluczone, że pewną rolę odegrały tu również potencjalne kontrakcje w praesens typu 3sg. chłodnieje (: chłodnieć) obok chłodnie (: chłodnać) oraz konwergencja gerundiów obu typów ( ${ }^{\star} \chi o l d-b n-\check{e}-n$-bj-e $>$ chłodnienie $\left.<{ }^{*} \chi o l d-n e-n-b j-e\right)$.

${ }^{8} \mathrm{~W}$ obu punktach przytoczyć wypadło również po jednym przymiotniku z dającym się wydzielić na poziomie synchronicznym sufiksem -k-. Ze względu na niewątpliwą wtórność oraz niewielką liczbę przykładów traktuję to zagadnienie jako drugorzędne.

9 Okoliczność ta zmusza mnie do usunięcia pewnej liczby przykładów, które, potencjalnie wspierając hipotezę Lorentza, nie spełniają jednak przyjętych przeze mnie kryteriów chronologicznych i arealnych (z drugiej strony pomijam także kilka - choć mniej - przykładów, które 


\section{Dobór i układ materiału}

Przeprowadzona przeze mnie kwerenda wskazuje, że zlokalizowane geograficznie formy na -ńeišs- (uogólniona postać kaszubska) w najszerszym zakresie poświadczone zostały w materiałach słowińskich F. Lorentza. Z tego względu dokonałem ekscerpcji tekstów słowińskich wydanych przez A. F. Hilferdinga (Gil'ferding, 1862, ss. 90-112), F. Lorentza (Lorentz, 1905) oraz M. Rudnickiego (Rudnicki, 1913, ss. 132-191). Dodatkowo ekscerpowałem pozostałe teksty u Hilferdinga, resztę tekstów północnokaszubskich Lorentza (Lorentz, 1913) oraz teksty bylackie w zapisach G. Bronischa (Bronisch, 1898). Efekt był jednak nieco zaskakujący - w opublikowanych tekstach takie formy właściwie się nie pojawiają. Co więcej, nawet Slovinzische Grammatik Lorentza z 1903 r. nie zawiera jeszcze precyzyjnej informacji o interesującym nas typie, zanotowano tam bowiem - bez komentarza - jedynie postaci comp. adi. mjąžniešsii, adv. mjąžńé do mjöúušši 'gruby' (Lorentz, 1903, ss. 288-289).

W tej sytuacji głównym źródłem zlokalizowanych zapisów okazuje się Slovinzisches Wörterbuch Lorentza $z$ lat 1908-1912 (SW, 1908-1912). Nie można tu pominąć faktu, że dzieło to podlegało w swoim czasie ostrej krytyce. Przytoczyć tu warto zwłaszcza uwagi K. Nitscha, który raczej niebezzasadnie podejrzewał, że „autor bardzo znacznej ilości przytoczonych słów nie posłyszał przypadkiem, lecz że użycie ich wywołał” (Nitsch, 1909, s. 51), ponadto „bodaj czy niektóre z nich nie są raczej próbami twórczości językowej, podobnej do pracy tłumaczącego książkę fachową, gdzie co chwila spotyka się z pojęciami, nie przekraczającymi wprawdzie jego zakresu, ale nigdy dotąd nie nazwanemi” (Nitsch, 1909, s. 53). Por. także uwagi Rudnickiego na temat sposobu zbierania materiału przez Lorentza (Rudnicki, 1913, s. 5, przyp.). Co do comparatiwów, Nitsch krytykował nie tylko samą ich lemmatyzację (bez stosownych odsyłaczy przy positiwach), lecz także

mogłyby na podobnej zasadzie wspierać hipotezę czasownikową). Część positiwów na - $n$ - da się objaśnić jako formacje dotworzone (niekiedy może nawet sztucznie, przez autorów opracowań) do czasownika lub wręcz do nowego comparatiwu. Specyficzne stosunki panują w gnieździe przymiotnika snáứži 'hübsch, schön, ładny, piękny', gdzie zapewne postać bezsufiksalna została wtórnie dotworzona do pierwotnych formacji sufiksalnych positiwu na - $n$ - i comparatiwu na -ń- (inaczej SEK, 1994-2010, t. 4, s. 338).W niektórych przypadkach positiwy na - n- różnią się pod względem znaczenia od odpowiedników bezsufiksalnych i nie mogą być traktowane jako warianty. Inne przykłady należy znowuż odrzucić z uwagi na skąpe i niepewne poświadczenia, oddalenie geograficzne od Kaszubszczyzny lub wydatne różnice chronologiczne. Pierwotna wersja artykułu uwzględniała i szczegółowo referowała wszystkie te przykłady; jest ona dostępna u autora. 
wyodrębnienie wszystkich wariantów morfologicznych oraz fonetycznych (Nitsch, 1909, ss. 47-48). W istocie wiele form comparatiwu w SW sprawia wrażenie wręcz sztucznie dopisanych na podstawie znajomości różnic fonetycznych między gwarami poszczególnych wsi. Tak na przykład dla wyrazów zeltitonï 'zielony', zielıno 'zielono', wyrażających przecież pojęcie nieczęsto podlegające stopniowaniu, odnotowano w sumie aż sześć form stopnia wyższego s.v.: zelẽinš̌i

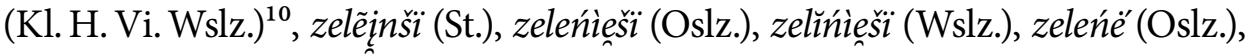
zelińé( Wslz.) (SW, 1908-1912, s. 1412), które „szczęśliwym trafem” wypełniają całą matrycę możliwych do przewidzenia wariantów, przy uwzględnieniu widocznie powszechnej wówczas na tym terenie - oboczności morfologicznej form przymiotnikowych oraz specyfiki fonetycznej konkretnych lokalizacji.

Tym niemniej dla wiarygodności przekazów Lorentza posiadają znaczenie jeszcze następujące przesłanki. Warto zwrócić uwagę, że Rudnicki, który znał dobrze omówienie Nitscha, w swoich przyczynkach (Rudnicki, 1913) odnotowywał głównie to, co w świetle jego własnych badań nie zgadzało się z opracowaniami Lorentza. Otóż żadnych uwag krytycznych w odniesieniu do comparatiwów, także tych na -ń-, u Rudnickiego nie znajdujemy. Po drugie, materiał ten z całą pewnością nie służył jakiejś „programowej” ilustracji zasad gramatycznych wyłożonych wcześniej przez Lorentza w Slovinzische Grammatik - najwyraźniej odzwierciedlał on bowiem tendencję, na którą uczony zwrócił uwagę dopiero później, po dłuższym obcowaniu z dialektem, a może przejawiającą się wyraźniej w pewnych tylko sytuacjach komunikacyjnych, wymagających bliższego kontaktu eksploratora $\mathrm{z}$ użytkownikami wymierającego narzecza o bardzo niskim prestiżu. Faktu tego nie odnotował także w Kaschubische Grammatik (Lorentz, 1919, ss. 23-24), choć ostatecznie omawianą tendencję zidentyfikował na szerszym obszarze kaszubskim: „Sufiks ten występuje we wszystkich gwarach [kaszubskich - autor] dość często" (GP, 1927-1937, s. 774) ${ }^{11}$; niestety, w późniejszych dziełach (GP, 1927-1937; PW, 1958-1983) odnośne formy zazwyczaj nie są opatrzone informacją o lokalizacji. Zapisy w Atlasie językowym kaszubszczyzny... (nieobejmującym przecież słowińskiego) są już dość nieliczne (AJK, 1964-1978, t. 9, ss. 130, 134, 138-139).

10 Skróty służące lokalizacji form objaśnione są w SW, zob. SW, 1908-1912, s. II.

${ }^{11}$ Por. też: 1. „Sehr beliebt ist das von den Adjektiven auf -nï abstrahierte Suffix -ńeiši [...]”, 2. “[...] und die Bildung von einem durch - $n$ - erwieterten Stamme ist sehr beliebt [...]” (1. „Bardzo popularny jest sufiks -ńeîsí, wyabstrahowany z przymiotników na -níi [...]”, 2. „[...] i bardzo popularna jest formacja od tematów rozszerzonych za pomocą - $n$ - [...]”) (Lorentz, 1925, ss. 133, 145). 
Kontrola materiału słowińskiego nie jest już, rzecz jasna, możliwa. Przyjmując za podstawę zapisy z SW (SW, 1908-1912), zakładam (!) ich wiarygodność pod względem odzwierciedlenia form stopnia wyższego na -ń- w danym gnieździe wyrazowym; z mniejszą pewnością skłonny jestem za to podchodzić do dokumentacji poszczególnych wariantów fonetycznych wraz z lokalizacjami. Każdą formę odnotowaną w SW (SW, 1908-1912) skontrolowałem w Pomoranisches Wörterbuch (PW, 1958-1983) oraz w słowniku B. Sychty (S, 1967-1976); pełną ekscerpcję tych (i innych, zwłaszcza środkowoi południowokaszubskich) źródeł pozostawiam do wykonania w ramach przyszłych badań ${ }^{12}$. Pomijam odniesienia do opracowania leksyki słowińskiej pod redakcją Z. Sobierajskiego (Sobierajski, 1997), jako niezawierającego dodatkowego materiału.

Odnotowane jednostki prezentuję w układzie hasłowym.

- Nagłówek hasła obejmuje kolejno:

a) wytłuszczone, oddzielone ukośnikiem zapisy podstawowych form positiwu przymiotnika i przysłówka bez sufiksu -n-/-ń- (ewentualnie z sufiksem $-k-$ ), z pominięciem wariantów fonetycznych; liczba po formie wskazuje strony, na których wystąpiła ona - już wraz z wariantami - w SW;

b) znaczenie przepisane z SW wraz z polską glosą;

c) odesłanie w nawiasie do odpowiedniego miejsca w PW.

- Od nowego wiersza następują formy comparatiwu. Z początku wymienione są zapisy form na -ń- z SW wraz z ewentualną lokalizacją (por. skróty w SW, 1908-1912, s. II) oraz numerem strony. Po znaku \| umieszczono pozostałe formy comparatiwu odnotowane w SW. Po kropce znajdują się komentarze nt. zasięgu form comp. na -ń- w kaszubszczyźnie lub inne zapisy form comparatiwu z materiałów słowińskich.

- Kolejny ustęp otwierają zapisy nieprzechodnich czasowników zmiany stanu na - $n$ - i/lub -ń- z SW wraz z numerami stron; w nawiasie wskazano odpowiednie miejsce w PW. Brak zapisu w SW oznaczony jest symbolem „”. Po kropce następują komentarze dotyczące historii oraz występowania czasownika w areale polsko-pomorskim - zwłaszcza na Kaszubach ${ }^{13}$.

${ }^{12}$ Np. w zarysach gramatycznych Ceynowy brak wzmianek o comparatiwach na -ń-.

13 Z zapisów historycznych pominąłem z Kart. SPXVI, b.d., participia i derywaty nominalne. Uzupełnienie tych informacji mogłoby jedynie wzmocnić argumentację budowaną 
- W następnym dziale wymienione są przymiotniki i przysłówki w positiwie na -n- (-ń-) z SW wraz z numerami stron; w nawiasie wskazano odpowiednie miejsce w PW. Brak zapisu w SW oznaczony jest symbolem „ø”. Po kropce następują komentarze dotyczące historii oraz występowania przymiotnika lub przysłówka $\mathrm{w}$ areale polsko-pomorskim - zwłaszcza na Kaszubach.

- Hasło kończy się ogólną konkluzją dotyczącą wymowy materiału oraz, ewentualnie, innymi komentarzami.

\subsection{Przymiotniki i przysłówki $(-ø-/-k-\sim-n-)^{14}$}

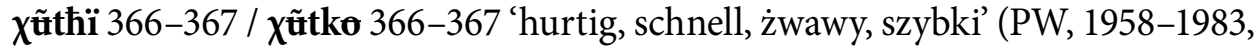
t. 1, s. 291).

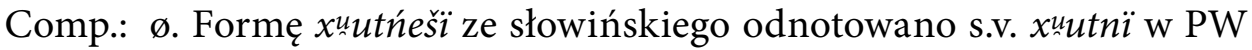
(PW, 1958-1983, t. 1, s. 291); lokalizacja comp. adv. xuntné nie została dopre-

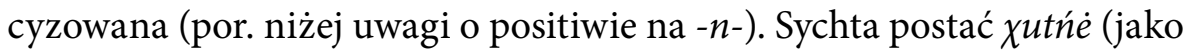

w ramach niniejszego artykułu, dzięki ewentualnemu przesunięciu wstecz datacji derywatów wybranych czasowników.

${ }^{14}$ Spoza słowińskiego należy tu wymienić poniższy przykład (odstępuję od przyjętego układu hasła właśnie ze względu na brak materiału słowińskiego): xądoǵi / xądogu u 'sauber, czysty' (PW, 1958-1983, t. 1, s. 271) : xądožni / xądožno 'proper, sauber, ordentlich, schludny, czysty, porządny' (PW, 1958-1983, t. 4, s. 1369). W PW początkowo zanotowano wyłącznie comp. na -ń- do bezsufiksalnego positiwu (PW, 1958-1983, t. 1, s. 271), podczas gdy positivus na -n- podano dopiero później za Sychtą (S, 1967-1976, t. 2, s. 24) oraz AJK (AJK, 1964-1978, t. 1, s. 125) (PW, 1958-1983, t. 4, s. 1369). Nie jest jasne, czy lokalizacja w PW s.vv. xądoǵi, xądogúo dotyczy również comp. na -ń- (adi.: Jastarnia pow. pucki, Goręczyno pow. kartuski; adv.: Jastarnia, Goręczyno, twórczość Ceynowy). U Sychty hasła na - $n$ - zaopatrzone są w cytaty z positiwami, por. także rzeczownik xądožnosc (S, 1967-1976, t. 2, s. 24); o ile przy bezsufiksalnym adi. podano wariant comp. z i bez -ń-, o tyle dla adv. - wyłącznie z -ń-. Według AJK wyraz nieznany na północy Kaszubszczyzny (również w słowińskim) poza Jastarnią oraz Nadolem (pow. wejherowski); w drugim z punktów odnotowano postać xądožni (AJK, 1964-1978, t. 1, s. 125) - poza tym zapisem form na - $n$ - w AJK nie ujawniono. Co ciekawe, adi. na - $n$ - $w$ dawnej polszczyźnie odnotowano początkowo w formie gradacyjnej, por. dwa zapisy superlatiwu w kazaniach Jana z Szamotuł (†1519), wydrukowanych w 1525 r. (SPXVI, 1956-2018, t. 3, s. 218). Por. dopiero w 1568 r. u M. Reja adv. chędożnie oraz w 1588 r. u A. Gostomskiego chędożniuchno. W XVI w. znacznie częściej: ochędożny, ochędożnie etc. (SPXVI, 1956-2018, t. 19, ss. 539-542). W gwarach, poza Kaszubami, wariant na - $n$ - notuje się tylko wyjątkowo (SGP, 1979-2018, t. 3, s. 494). Przykład wymaga dokładniejszego zbadania w źródłach z pozostałych terytoriów kaszubskich. 
comp. do $\chi$ utko) określa jako południową (S, 1967-1976, t. 2, s. 59). W AJK (AJK, 1964-1978, t. 9, s. 138) comp. adv. na -ń- notowany był wyłącznie na południu Kaszubszczyzny oraz - sporadycznie - poza jej granicami. Por. jeszcze uwagi H. Popowskiej-Taborskiej (Popowska-Taborska \& Rzetelska-Feleszko, 2009, s. 224) na temat materiału G. Wenkera.

Verb.: $\varnothing$.

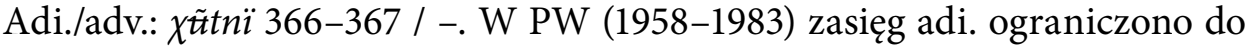
słowińskiego; podano również adv. xưutne (słi., Sikorzyno pow. kartuski, Rotembark, Grzybowo, Wdzydze, Popia Góra pow. kościerski, Czarnowo pow. chojnicki $\left.{ }^{15}\right)$ (PW, 1958-1983, t. 1, s. 291). Notowane od XVI w. (SPXVI, 1956-2018, t. 3, s. 342) ${ }^{16}$. W gwarach, poza Kaszubszczyzną, znane wyłącznie z Orawy i Śląska Cieszyńskiego (wpływ słowacki, może również czeski ${ }^{17}$ ) (SGP, 1979-2018, t. 4, s. 147). Zarówno w zabytkach, jak i - zwłaszcza - w gwarach południowych objawia się również znaczenie 'przyjemny, smaczny'.

Kom.: Zwracają uwagę rozbieżności pomiędzy źródłami. Po pierwsze, w SW podano jedynie positiwy (adi. i adv. na - $k$ - oraz wyłącznie adi. na - $n$-), podczas gdy PW zawiera także zapis słowińskiego comp. adi. na -ń- oraz nieprecyzyjnie zlokalizowany zapis comp. adv. na -ń-. Po drugie, w PW podano adv. na -ń- ze słowińskiego oraz z południa Kaszubszczyzny (wraz z formą comp. o niedoprecyzowanej lokalizacji i niezlokalizowanymi cytatami zawierającymi formę positiwu oraz superlatiwu), podczas gdy form positiwu adv. nie zawiera nie tylko SW, lecz także słownik Sychty (brak tu również form positiwu i comp. adi. na -n-l-ń-). Poza tym znaczenia przymiotników poza kaszubszczyzną (tj. m.in. w zabytkach) nie w pełni się pokrywają. Mimo zasygnalizowanych nieścisłości jest to przykład istotny, którego objaśnienie nie wymaga odwołania do kategorii werbalnych. Reprezentuje on jednak oboczność $-k-\sim-n-\mathrm{w}$ positiwie, trudno więc uznać go za model badanego tu stosunku - $-\sim-n-$.

15 Stąd pochodził J. Karnowski, do którego twórczości odwołano się w omawianym haśle. Nie jest jasne, czy chodzi także o niezależny zapis z tej miejscowości.

16 Całe gniazdo wyrazowe bazuje na bohemizmie chuć. W różnych okresach i areałach możliwe były także wtórne wpływy czeskie i słowackie (zob. niżej).

17 Ze Śląska Cieszyńskiego ściśle zlokalizowane przykłady pochodzą z tzw. Trójwsi Beskidzkiej. 
pù̀ozzä 909 / - 'spät, późno' (PW, 1958-1983, t. 2, s. 78).

Comp.: pozdńiensì 840, pozńiensì 841 / pozdńé 840 , pozńé 841 . Por. także zapisy comp. adv. požžé (Lorentz, 1903, s. 288; Rudnicki, 1913, s. 228; PW, 1958-1983, t. 2, s. 79) i jednokrotnie zapisaną w tekście formę pỏz"zèi (Rudnicki, 1913, s. 158). W ekscerpowanych tekstach słowińskich dwukrotnie zapisano formę comp. adv. na -ń- (Lorentz, 1905, s. 31; Rudnicki, 1913, s. 159).

Verb.: zaptuzzdnouc 909 (PW, 1958-1983, t. 2, s. 78). Poza słowińskim jednokrotnie odnotowane w utworze A. Budzisza (PW, 1958-1983, t. 2, s. 85). Niezależnym tworem jest spóźnieć, zapisane dwukrotnie w Lgocie Gawronnej (pow. częstochowski, Kart. SGP, b.d.).

Adi./adv.: póúznï 818 (PW, 1958-1983, t. 2, s. 85). Prawdopodobnie w słowińskim nie funkcjonował positivus adv. na -n-/-ń- (brak w SW, por. opatrzone gwiazdką * póúžnä w Lorentz, 1903, s. 289). W północnej kaszubszczyźnie adv. na - $n$ - było rzadkie - o ile Sychta (S, 1967-1976, t. 4, s. 157; PW, 1958-1983, t. 4, s. 1710) notował je na Półwyspie Helskim, o tyle w AJK (1964-1978, t. 7, ss. 221-222) brak już takich zapisów. Nie jest jasne, czy wszystkie lokalizacje podane w PW (1958-1983, t. 2, s. 85) odnoszą się do positiwu. Formy na - $n$-, o ogólnogwarowym zasięgu (Kart. SGP, b.d.), notowane są od XV w. (SStp, 1953-2002, t. 7, s. 20). Por. pol. lit. późny, późno.

Kom.: Starsze typy comparatiwu przysłówka zachowały się bodaj wyłącznie w słowińskim póz"zèi, pežžé'(por. scs. pozděje, ros. pozže); brak analogicznych przykładów dla stpol. positiwu poździe. Segment -n-l-ń-, nieobecny w przysłówku, on posłużył jako formant pochodnego przymiotnika póz(d)ny; objawia się on i w przymiotnikowym comparatiwie poźniejszy (pozdniejszy), por. słi. póuznï : poz(d)níešì. W toku rozwoju polszczyzna literacka przebudowała całe gniazdo, uogólniając strukturę z -n-/-ń-, charakterystyczną dla przymiotnika (adi. późny: comp. późniejszy, adv. późno : comp. później) ${ }^{18}$. Tymczasem w słowińskim stan pierwotny uległ zmianie tylko w jednym aspekcie: do odziedziczonego adv. pùtozzä dotworzono wariant comp. poz(d)ńë, na podstawie comp. adi. pez(d)ńiešïi. Sporadyczne formacje werbalne w gwarach są niewątpliwie wtórne.

${ }^{18}$ Może nawet w oparciu o comparativus - stąd chyba -ź- w positiwach (abstrahuję od rozwoju stosunków iloczasowych). Najistotniejsze jest tu jednak samo dotworzenie adv. późno ( pózdno) i comp. później (pozdniéj), a zwłaszcza wyrugowanie starego adv. poździe wraz z pierwotną, niepoświadczoną formą comparatiwu. 


\subsection{Czasowniki na $-n-/-n$ -}

bladî́ 45 / blãdo 46 'blass, blady' (PW, 1958-1983, t. 1, ss. 33-34).

Comp.: bladńieši 46 / bladńé 46 || blãtšï 48. Por. jeszcze słi. comp. adv. blazé (Lorentz, 1903, s. 288; Rudnicki, 1913, s. 225).

Verb.: blãdnouç, bladńáuc 45-46 (PW, 1958-1983, t. 1, s. 34, 36). Typ na -nąć notowany od poł. XV w. (SStp, 1953-2002, t. 11, s. 271), -nieć - od 1522 r. (Żywot Pana Jezu Krysta B. Opeca, SPXVI, 1956-2018, t. 2, s. 173); znane w gwarach (SGP, 1979-2018, t. 2, ss. 236, 254). Por. pol. lit. bladnąć, blednąć, blednieć.

Adi./adv.: ø. Adi. na $-n-\mathrm{w}$ gwarach polskich zanotowano jednokrotnie ${ }^{19}$ (Karaś, 1959, s. 117; SGP, 1979-2018, t. 2, s. 236) - na Kaszubach, w Goręczynie (pow. kartuski) (PW, 1958-1983, t. 1, s. 34; brak lokalizacji w GP, 19271937, s. 751). W tej samej okolicy zapisano derywat bladńica 'niedokrwistość' (Chmielno pow. kartuski), 'żółtaczka (?)' (Wdzydze pow. kościerski) (PW, 1958-1983, t. 1, s. 34). Por. pol. lit. blednica 'chloroza', a także XVI-wieczne bladność / bledność (SPXVI, 1956-2018, t. 2, s. 168). Są to wyrazy utworzone w oparciu o strukturę czasownika, z pominięciem pośredniego - potencjalnego - stadium przymiotnikowego. Por. też kasz. sufiks -ńica (GP, 1927-1937, s. 703).

Kom.: Prawdopodobny wpływ odziedziczonego verb. Zapewne brak bezpośredniego związku kasz. adi. na - $n$ - ze słowińskim comp. (por. znikomy zasięg adi. oraz oddalenie punktów); owo adi. wydaje się wręcz derywatem wstecznym od verb. (a może i comp.), podobnie jak analogiczne wyrazy w innych językach słowiańskich (por. SP, 1974-2001, t. 1, s. 260).

čvjărdî́ 150-151 / čvjărdo 151-152 (PW, 1958-1983, t. 1, s. 120).

Comp.: čvărḍinešsi H. Vi. St. Wslz. 151, čvjărdńiešsi Kl. 152 / čvărdńé H. Vi. St.

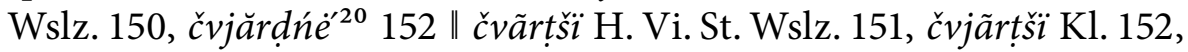
čvjierț̌si 154 . W ekscerpowanych tekstach słowińskich zapisano po jednej formie comp. i superlatiwu bez segmentu -ń-: 'čvjarț̌se, 'nåučcvjartše (Rudnicki, 1913, ss. 155, 157). W AJK we wschodniej części pow. puckiego jednokrotnie zanotowano postać comp. adi. na -ń- (pkt 16. Sławutowo, AJK, 1964-1978, t. 9, s. 130), a kilkukrotnie - adv. (pkty 6. Wielka Wieś

19 Wyłączając słi. comparativus, uwzględniony w SGP, zob. SGP, 1979-2018, s.v. bladny.

${ }^{20}$ Pominięto lokalizację. Zapewne: Kl. 
[obecnie Władysławowo], 8. Bór [obecnie część Helu], 9. Gnieżdżewo, 16. Sławutowo - AJK, 1964-1978, t. 9, s. 139); za niepewny uznano zapis comp. adv. tvardńe na południowym zachodzie Kaszubszczyzny, ze wsi Upiłka (pow. bytowski, pkt 136) - podobnych wątpliwości nie wzbudziła jednak u autorów antonimiczna forma miątńie $\mathrm{z}$ tego samego punktu (AJK, 1964-1978, t. 9, s. 134).

Verb.: čvjãrdnouc 150-152 (PW, 1958-1983, t. 1, s. 120). Oba warianty sufiksalne notowane od 1534 r. (O ziołach i o mocy ich S. Falimirza, Kart. SPXVI, b.d., hasła stwardnieć (się), twardnąć, twardnieć); znane z gwar (Kart. SGP, b.d.). Por. pol. lit. twardnieć.

Adi./adv.: ø.

Kom.: Prawdopodobny wpływ odziedziczonego verb. (mimo braku w materiale słowińskim wariantu na -ńáuc).

gąstî́ 265 / gąasto 266 'dicht, gęsty' (PW, 1958-1983, t. 1, s. 206).

Comp.: gąstńieñĭ 266 / gąstńé265 || gasciešši 265, gãstši 266 / gą̌ščé266. W PW nie dookreślono zasięgu comp. adi. i adv. na -ń- (możliwe występowanie także poza słowińskim); postać sufiksu adi. (-ńeš-) mogłaby jednak wskazywać na związek $z$ areałem słowińskim. W ekscerpowanych tekstach słowińskich dwukrotnie zapisano formę comp. bez segmentu -ń-: adv. gas'cèi, neutr. ga'ščè (Rudnicki, 1913, ss. 155, 173).

Verb.: gąstńáuc 265-266 (PW, 1958-1983, t. 1, s. 206). Oba warianty sufiksalne notowane od 1534 r. (O ziołach i o mocy ich S. Falimirza, Kart. SPXVI, b.d., hasła zgęstnąć (się), zgęstnieć (się)); znane z gwar (SGP, 1977-2018, t. 8, s. 308). Por. pol. lit. gęstnąć, gęstnieć.

Adi./adv.: $\varnothing$.

Kom.: Prawdopodobny wpływ odziedziczonego verb.

glắư⿱tï 268, 273 / glắuntko 268, 273 'glatt, gładki' (PW, 1958-1983, t. 1, s. 215). Comp.: gladńieši 267 / gladńé267 || glãtkšĭ 269 / glazë268, glatčé269.

Verb.: glãdnouc, gladńáuc 266-267 (PW, 1958-1983, t. 1, s. 210). Verb. - odnoszące się do stanu powierzchni wody (morza lub jeziora) - znane także z Jastarni (pow. pucki) (PW, 1958-1983, t. 1, s. 210; S, 1967-1976, t. 1, s. 321) oraz Karwi (S, 1967-1976, t. 1, s. 321). Postać na -nać notowana od 1579 r. (SPXVI, 1956-2018, t. 7, ss. 360-361), -nieć - od 1621 r. (Knapski); por. dawne pol. lit. gładnieć. W innych gwarach nieznane.

Adi./adv.: ø. 
Kom.: Prawdopodobny wpływ verb. Przykład reprezentuje jednak relację adi. $-k-$ : verb. - n-/-ń-, trudno więc uznać go za model badanego tu stosunku $-\emptyset-\sim-n-^{21}$.

geřhî́ 291 / gùơřke 317 'bitter, gorzki' (PW, 1958-1983, t. 1, s. 249).

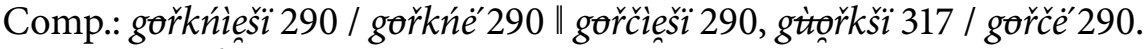

Verb.: gəřknááuc, gìtořknouc 290, 316-317 (PW, 1958-1983, t. 1, s. 249). Obie postaci notowane od 1535 r. (SPXVI, 1956-2018, t. 8, s. 40; zgorzknać Gadki z pisma wielkiego filozofa Arystotela A. Glabera, Kart. SPXVI, b.d.) ${ }^{22}$; znane z gwar (SGP, 1979-2018, t. 8, s. 647). Por. pol. lit. gorzknąć, gorzknieć. Adi./adv.: ø.

Kom.: Prawdopodobny wpływ odziedziczonego verb.

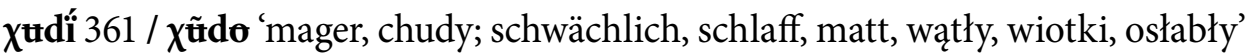
(PW, 1958-1983, t. 1, ss. 289-290).

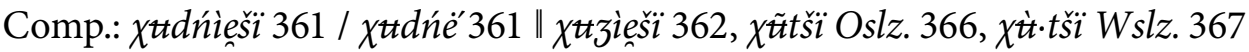

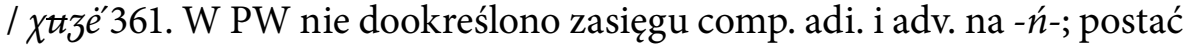
sufiksu adi. (-ńeš-) mogłaby jednak wskazywać na związek $\mathrm{z}$ areałem słowińskim. W ekscerpowanych tekstach słowińskich jednokrotnie zapisano formę superlatiwu bez segmentu -ń- : náux xŭť̌̀e (Lorentz, 1905, s. 118).

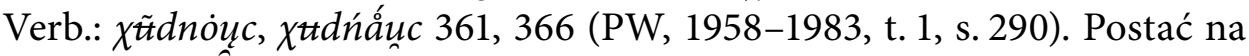
-nać notowana od 1436 r. (SStp, 1953-2002, t. 1, s. 260), -nieć - od 1558 r. (SPXVI, 1956-2018, t. 3, s. 335); znane z gwar (SGP, 1979-2018, t. 4, ss. $123-$ 124). Por. pol. lit. chudnąć, również daw. chudnieć.

Adi./adv.: $\varnothing$.

Kom.: Prawdopodobny wpływ odziedziczonego verb.

slabî́ 1042 / slãbo 1042 'schwach, słaby' (PW, 1958-1983, t. 2, s. 278).

Comp.: slabńiešï 1042 / slabńé 1042 || slãpši 1044. Por. jeszcze slabjé(Lorentz, 1903, s. 288; Rudnicki, 1913, s. 229). W PW nie dookreślono zasięgu comp. adi. na -ń-; postać sufiksu adi. (-ńeš-) mogłaby jednak wskazywać na związek $\mathrm{z}$ areałem słowińskim.

${ }^{21}$ Co do stosunku adi. - $k$ - : verb. -n-/-ń-, por. w polskim serię gładki : daw. gładnąć gładnieć, rzadki : rzednaćc $\sim$ rzednieć, słodki : daw. słodnąć słodnieć etc.

${ }^{22}$ Por. jeszcze derywat o nietypowej budowie z 1534 r.: przygorzknący (SPXVI, 1956-2018, t. 33 , s. 212). 
Verb.: slãbnóuc 1042. Postać na -nać notowana od 1471 r. (SStp, 1953-2002, t. 5, s. 653), -nieć od 1674 r. (u W. Kochowskiego, por. Grappin, 1947, s. 123); znane z gwar (Kart. SGP, b.d.). Por. pol. lit. słabnąć, również daw. słabnieć. Adi./adv.: ø. Wyjątkowo zanotowano rzeczownik słabności w okolicy Stawiszyna (pow. kaliski; Ciszewski, 1916, s. 98).

Kom.: Prawdopodobny wpływ odziedziczonego verb. (mimo braku w materiale słi. wariantu na -ńáúc).

\section{Podsumowanie}

Powyższa analiza wskazuje, że udział nieprzechodnich czasowników zmiany stanu typu gąstnec $\sim$ gastnoc w rozpowszechnieniu segmentu -ń- $\mathrm{w}$ formancie comparatiwu (np. gastńeiši) jest prawdopodobny. Świadczy o tym - w mojej opinii - zarysowany mechanizm innowacji (por. 1) oraz dobre osadzenie wskazanych typów werbalnych w historii narzecza (por. 3.2). Por. bladï - bladnaáuc,

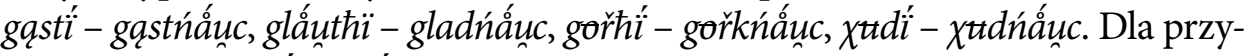
miotników čvjărdï i slabḯ w materiale słowińskim nie odnotowano czasowników wskazanego typu, a jedynie čvjãrdnouc, slãbnouc; jednakże, ze względu na istnienie w słowińskim obu typów dla ponad połowy interesujących nas w tym miejscu

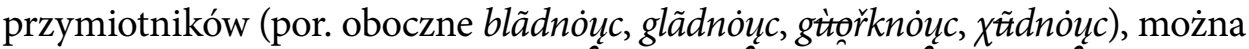
przypuścić, że od pewnego etapu szczegóły budowy czasownika nie były już tak istotne ${ }^{23}$. W każdym z przypadków którąś z postaci czasownika udokumentowano w polszczyźnie co najmniej od XVI w. (postaci na -nąć są zasadniczo starsze), obie zaś postaci - najpóźniej do XVII w.; są one też znane w innych gwarach polskich, z wyjątkiem gladńáuc glãdnơuc. Należy zauważyć, że spośród wymienionych przymiotników jedynie bladï posiada wariant sufiksalny positiwu - jest to jednak „hapaks gwarowy” (wprawdzie kaszubski, ale nie słowiński).

Istotne są jednak następujące zastrzeżenia. Po pierwsze, wnioskowanie opiera się w głównej mierze na interpretacji materiału z jednego źródła (SW), które nie pod wszystkimi względami uznaje się za w pełni wiarygodne (por. 1); konieczne są zatem dalsze badania $\mathrm{z}$ uwzględnieniem obszerniejszego materiału kaszubskiego spoza Słowińszczyzny. Warto odwołać się w tym miejscu do materiału

${ }^{23}$ O ścisłych związkach zachodzących między oboma typami świadczy również wprowadzenie -ń- na miejsce $-n-\mathrm{w}$ temacie formy 1sg. praes. do inf. typu blãdnouc, por. blãdńa zamiast oczekiwanego ${ }^{\star}$ blãdną. 
AJK, który ukazuje interesujące formy także ze wschodniej części północnej Kaszubszczyzny oraz z jednego punktu na peryferii południowo-zachodniej ${ }^{24}$. Po drugie, sugerowanego przez Lorentza udziału obocznych postaci przymiotników i przysłówków $(-\varnothing-\sim-n-)$ w omawianym procesie nie tylko nie da się wykluczyć, lecz także w pewnym zakresie wydaje się on wręcz nieunikniony; chodzi tu zwłaszcza o parę stpol. adv. poździe : adi. póz(d)ny (por. 3.1).

Na korzyść hipotezy czasownikowej przemawia ostatecznie większa liczba przykładów uznanych - w świetle przyjętych kryteriów - za prawdopodobne

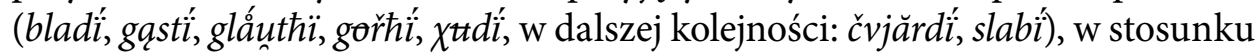
do wariantywnych struktur przymiotników i przysłówków (pitozzzä, $\chi \tilde{u} t \hbar \ddot{i}$, spoza słowińskiego: xądoǵi).

\section{Wykaz skrótów}

$\begin{array}{ll}\text { AJK } & \text { - Atlas jezykowy Kaszubszczyzny (Popowska-Taborska \& Stieber, 1964-1978) } \\ \text { GP } & \text { - Gramatyka pomorska (Lorentz, 1927-1937) } \\ \text { Kart. SGP } & \text { - Kartoteka Stownika gwar polskich (b.d.) } \\ \text { Kart. SPXVI - Kartoteka Stownika polszczyzny XVI wieku (b.d.) } \\ \text { PW } & \text { - Pomoranisches Wörterbuch (Lorentz, 1958-1983) } \\ \text { S } & \text { - Stownik gwar kaszubskich na tle kultury ludowej (Sychta, 1967-1976) } \\ \text { SEK } & \text { - Stownik etymologiczny kaszubszczyzny (Boryś \& Popowska-Taborska, 1994-2010) } \\ \text { SGP } & \text { - Stownik gwar polskich (Karaś, Reichan, Okoniowa, \& Kucharczyk, 1979-2018) } \\ \text { SP } & \text { - Stownik prastowiański (Sławski, F. 1974-2001) } \\ \text { SPXVI } & \text { - Stownikpolszczyzny XVI wieku (Mayenowa, 1956-2018) } \\ \text { SW } & \text { - Slovinzisches Wörterbuch (Lorentz, 1908-1912) } \\ \text { SStp } & - \text { Stownik staropolski (Urbańczyk, 1953-2002) }\end{array}$

\section{Bibliografia}

Boryś, W., \& Popowska-Taborska, H. (1994-2010). Słownik etymologiczny kaszubszczyzny [SEK] (T. 1-6). Warszawa: Slawistyczny Ośrodek Wydawniczy.

${ }^{24}$ Upiłka (pow. bytowski, pkt 136). Chodzi o formy miątńie (AJK, 1964-1978, t. 9, s. 134) oraz - z nie całkiem jasnymi zastrzeżeniami ze strony redaktorów - tvardńe (AJK, 1964-1978, t. 9, s. 139) (zob. wyżej). 
Bronisch, G. (1898). Kaschubische Dialectstudien: Zweites Heft. Texte in der Sprache der Bélồcë. Leipzig: Otto Harrassowitz.

Ciszewski, S. (1916). Przyczynek do słownika gwary wielkopolskiej. Prace Filologiczne, 8, 94-100.

Gil'ferding, A. F. (1862). Ostatki slavian na iuzhnom beregu Baltiǔskogo moria. Ėtnograficheskǐ sbornik, 1862(5), 1-191.

Grappin, H. (1947). Le suffixe nasal dans la morphologie du verbe polonais. Revue des études slaves, 23(1-4), 120-129. https://doi.org/10.3406/slave.1947.1453

Karaś, M. (1959). O strukturach słowotwórczych typu białny, którny w języku polskim. Biuletyn Polskiego Towarzystwa Językoznawczego, 18, 113-135.

Karaś, M., Reichan, J., Okoniowa, J., \& Kucharczyk, R. (Red.). (1979-2018). Słownik gwar polskich [SGP] (Vols. 1-10/1). Kraków: IJP PAN.

Kartoteka Słownika gwar polskich [Kart. SGP]. (b.d.). Pobrano z http://rcin.org.pl/publication /37156

Kartoteka Słownika polszczyzny XVI w. [Kart SPXVI] (b.d.). Pobrano z http://www.rcin.org.pl /publication/23662

Lorentz, F. (1903). Slovinzische Grammatik. Berlin: Akademie Verlag.

Lorentz, F. (1905). Slovinzische Texte. St. Petersburg: Buchdruckerei der Kaiserlichen Akademie der Wissenschaften.

Lorentz, F. (1908-1912). Slovinzisches Wörterbuch [SW] (T. 1-2). St. Petersburg: Buchdruckerei der Kaiserlichen Akademie der Wissenschaften.

Lorentz, F. (1913). Teksty pomorskie czyli kaszubsko-słowińskie. Kraków: Nakładem AU.

Lorentz, F. (1919). Kaschubische Grammatik. Danzig: Gedania E. G.m.b.H.

Lorentz, F. (1925). Geschichte der pomoranischen (kaschubischen) Sprache. Berlin: Walter de Gruyter \& Co.

Lorentz, F. (1927-1937). Gramatyka pomorska [GP] (T. 1-8). Poznań: Instytut Zachodniosłowiański.

Lorentz, F. (1958-1983). Pomoranisches Wörterbuch [PW] (T. 1-5). Berlin: Akademie Verlag.

Mayenowa, M. R. (Red.). (1956-2018). Słownik polszczyzny XVI wieku [SPXVI] (T. 1-37). Warszawa: IBL PAN.

Nitsch, K. (1909). Slovinzisches Wörterbuch Lorentza [rec.]. Rocznik Slawistyczny, 2, 43-56.

Popowska-Taborska, H., \& Rzetelska-Feleszko, E. (2009). Dialekty kaszubskie w świetle XIX-wiecznych materiałów archiwalnych. Warszawa: SOW.

Popowska-Taborska, H., \& Stieber, Z. (Red.). (1964-1978). Atlas językowy Kaszubszczyzny i dialektów sąsiednich [AJK] (T. 1-15). Wrocław, Warszawa, Kraków, Gdańsk: Zakład Narodowy im. Ossolińskich.

Rudnicki, M. (1913). Przyczynki do gramatyki i słownika narzecza słowińskiego. Kraków: Nakładem AU.

Sławski, F. (Red.). (1974-2001). Słownik prasłowiański [SP] (T. 1-8). Wrocław: Zakład Narodowy im. Ossolińskich. 
Sobierajski, Z. (Red.). (1997). Słownik gwarowy tzw. Słowińców kaszubskich. Warszawa: SOW. Sychta, B. (1967-1976). Słownik gwar kaszubskich na tle kultury ludowej [S] (T. 1-7). Wrocław, Warszawa, Kraków: Zakład Narodowy im. Ossolińskich.

Szeptyński, R. (2017). Vocalic elements and prosody in Slavic comparatives. Indogermanische Forschungen, 122(1), 189-205. https://doi.org/10.1515/if-2017-0008

Urbańczyk, S. (Red.). (1953-2002). Słownik staropolski [SStp] (T. 1-11). Kraków: IJP PAN.

\section{The Slovincian Comparative as a Parallel for Reconstructed Prehistoric Phenomena}

\section{Summary}

This article deals with an innovative type of comparatives in Slovincian (Kashubian) (cf., e.g. gastne $i$ iši 'thicker' $\leftarrow$ gastï 'thick', as opposed to the inherited forms gast $s^{\prime} i$, gasceišì). The -ń- extension of the formative originates from intransitive change-of-state verbs of the type gastnec 'to become thick(er)' $\leftarrow$ gastï. This phenomenon reflects a more general tendency in the development of Slavic and Indo-European languages. The significance of the Slovincian material is that it provides synchronic evidence from the first half of the twentieth century.

\section{Słowiński comparativus jako paralela dla rekonstruowanych zjawisk przedhistorycznych}

\section{Streszczenie}

Niniejszy artykuł dotyczy pewnego innowacyjnego typu comparatiwów w słowińskim (kaszubskim) (por. np. gastńeiši ' 'gęstszy' $\leftarrow$ gastï 'gęsty' wobec odziedziczonych gąstši, gąsceišì). Rozszerzenie -ń- w wykładniku wywodzi się z nieprzechodnich czasowników zmiany stanu typu gąstńec 'gęstnieć' $\leftarrow$ gąsti. Zjawisko to odzwierciedla ogólniejszą tendencję w rozwoju języków 
Rafał Szeptyński Słowiński comparativus jako paralela dla rekonstruowanych zjawisk...

słowiańskich i indoeuropejskich. Znaczenie materiału słowińskiego polega na możliwości potwierdzenia procesu na poziomie synchronicznym w pierwszej połowie XX wieku.

Keywords: comparative suffix; intransitive change-of-state verb; Kashubian dialects

Słowa kluczowe: sufiks stopnia wyższego; nieprzechodni czasownik zmiany stanu; dialekty kaszubskie

Rafał Szeptyński, Institute of the Polish Language, Polish Academy of Sciences, Cracow

ORCID: https://orcid.org/0000-0003-2292-4151

Correspondence: rafal.szeptynski@ijp.pan.pl

The preparation of this article was financed within the statutory activity of the Institute of the Polish Language, Polish Academy of Sciences.

Competing interests: The author declares that he has no competing interests. 